\title{
Wisdom in the poetry of Ahmad Shawqi
}

\author{
Nada Yousuf Al-Rifai (2017) \\ College of Basic Education, PAAET, Kuwait.
}

\begin{abstract}
Ahmad Shawqi lived between 1868 and 1932 and witnessed many events experienced by Arab and Islamic nations. These events greatly impacted his life and his poetry. He lived in Egypt from before the occupation of semi-independence and lived through the Orabi Revolution. He witnessed the British occupation of Egypt as well as the national movement led by Mustafa Kamel and Mohamed Farid. He was later exiled to Spain by the British after the First World War in 1914 and the deposition of Khedive Abbas. He advocated the 1919 revolution that erupted in Egypt, praising the fighters and watching the national strife in exile. Upon victory, he returned from his exile in 1920 . Shawqi was influenced by European lifestyle during his stay in France and Britain, but this did not take away his eastern origins and roots. Shawqi's poetry immortalized the events of his time. His poetry collection reflects an important era in the history of Egypt, the State of the Caliphate, and all Arab countries.
\end{abstract}

\section{INTRODUCTION}

This is a man who seems to me as if Egypt chose him from among all its people as the spokesperson of its spirit. Only through him can Egypt say to history, "my poetry, my literature!" [Shawqi] is a name that is to literature as the sun is to the east: whenever it rises to its a position, it rises in every place, and when mentioned in the Arab world, the meaning of his name expanded to indicate the whole of Egypt as if it were the Nile or the pyramids or Cairo. People live through youth, adulthood, and senility, but the true man of letters lives youth, adulthood, and youth again, as long as the living poetic aims are there within his heart. (AlRafi'ei, 2001, p. 279)

Ahmad Shawqi is one of the most prominent contemporary poets of not only Egypt, but also the Arab and Western world. He represents a certain artistic stage in the history of modern Arabic poetry. Following the approach of his teacher, Mahmoud Sami Al-Baroudi, Shawqi played an important role in reviving the literary movement and counting its constituents of great heritage. This movement was a new beginning in Arab poetry that followed a long period of inertia. Shawqi was also the poet of patriotism, who recorded the events of Egypt in his poetry, sang for its love, glorifying its great past and bright present, feeling sad for its weaknesses, and urging the people of Egypt to support their country.

Shawqi also witnessed momentous events in the Muslim world at a time when Turkey, the Ottoman Caliphate state at the time, was losing many of its mandates. It abandoned Algeria to France in 1830, followed by Tunisia in 1881. England then occupied Egypt and Sudan in 1882, while Italy occupied Tripoli in 1912. Independent Islamic states such as Afghanistan and Iran were also not safe from the gamesmanship of colonialism.

Shawqi was able to combine the old and the modern by providing Islamic character to the old religions and highlighting the call of monotheism by religions since ancient times. This trend also prevailed in Shawqi's theatrical poetry as well, which confirms the artistic and topical fact that Shawqi was keen to provide his themes with an Islamic tincture. Shawqi's historical poetry is full of names: events, people, and things, in which he imbued his portraits and artistic 
tools to accommodate his poetry and give it a tinge of Islamic holiness. Shawqi opposed and imitated many old poets, and his poetic emulation (or Mu'arada) formed a large part of his poetry collection. In addition to being inspired by other poets, Shawqi made rounds in the history of Arabic literature by making contact with the authors of books and being inspired by them. Shawqi was partially inspired by this literary heritage. Wisdom formed the greatest part of his poetry collection due to its importance. In the introduction to "Al-Shawqiyat," Dr. Mohamed Hussein Heikal writes:

Shawqi studied in Egypt, completed his studies in Europe, and was significantly influenced by European media, lifestyles, and poetry. This influence remained visible in his life and in his poetry, and one almost feels upon reviewing parts of his poetry collection that he is two different men with no connection between one and the other, except that both are poets by nature at the top levels of poetry, and both are Egyptians whose love for Egypt extended to the levels of sanctification and worship. Apart from this, each of the two men is not like the other. One is a believer whose soul is filled with faith, a Muslim who sanctifies the brotherhood of Muslims and makes the Caliphate State a holy one and of which affairs and events overflow within him as poetry and inspiration. He is a wise man who sees wisdom as the cadre and support of life. He is a conservative who sees that the Arabic language accommodates each image, meaning, idea, and imagination. The other is a worldly man who sees in the pleasures and bliss of life its best hopes and objectives. He is a tolerant person whose soul encompasses humanity, a sarcastic person encompassing people and their aspirations, and an innovator in language in its words and meanings. ("Al-Shawqiyat", page 6.)

Shawqi combined chronicled events of his time at the Egyptian, Arab, and Islamic levels, as well as past events. The wisdom in Shawqi's historical poetry came in the forms of preaching, lessons, and reflections on past events. "There are many proverbs in the poetry of Shawqi, and none of his poems are devoid them, especially his politics and socialites and elegies, and they are even sometimes found in his courtship poetry" (Al-Jarim, 1992, p. 352). Ahmad Shawqi traveled to France to study law in the city of Montpellier. Eager to tour, he travelled to Britain, Spain, and Algeria, and he was influenced by dramatic literature in Europe. He witnessed Britain's occupation of Egypt in 1882 when he was less than fifteen years old. He was contemporaneous with a number of the sons and grandsons of the Egyptian ruler Ali Pasha, the most famous of whom were Khedive Tawfiq and his son, Abbas Hilmi.

The Civic Education whose basics were set by Muhammad Ali in Egypt and grown and intensified by Ismail bore promising fruits after the Nationalist Revolution in 1919. It was one of the greatest factors that helped the Middle make contact with the West, as was the rising education in Syria and Lebanon in particular. The efforts of missionaries in this regard cannot be denied as the Arab students in Cairo, Beirut, Damascus, Baghdad, and even in the high schools became acquainted with Western literature. (Al-Dusouqi, 1951, p. 4)

Shawqi was not distant from the English actions in Egypt and elsewhere and the actions of the French Army in the Levant and other places. He remained passionate and sensible, living for the people and struggling in estrangement, especially after he moved away from the palace's men. He remained so until his death in 1932. Shawqi's sea of wisdom covers a wide and diverse range of topics. Wisdom was mentioned in a number of Shawqi's poems on multiple occasions and for a variety of purposes. It is scattered within the fabric of the poems and not for an independent purpose. 


\section{Shawqi's Stature}

"No poet similar to Shawqi has appeared within a thousand years" (Shafiq Jabri, 1997, p. 9). According to Mansour Fahmi, Shawqi was keen to bring together in his poetry the wholeness that he extracted out of science, history, social life, and the particulars of the human self. He used to say, "Poetry is the son of its parents; history and nature." In one of his lines, he writes, "Poetry, unless it were memory and emotion or wisdom, is nothing but rhymes and rhythms."

Based on a philosophical tendency towards wholeness and framing poetry in this mode, Shawqi revealed description, socialites, asceticism, and religiousness in his similes, from which unfold beauty in its splendor, wisdom in its jurisdiction, and philosophy in its soul through many examples (Ubayd, 1933, p. 495). Shawqi, like the philosophers, felt the beauty of the existence and life that is spread out in opposite directions, and one might thus see a contradiction in his terms, while in fact there is no contradiction (Ubayd, 1933, p. 498). According to Shawqi Daif, Shawqi is the brightest poet in the history of modern Arab literature due to the multiplicity of his artistic aspects and the diversity of his literary works" (Daif, 2010, p. 5). Antoine Al-Jemeil, said:

We have not known a poet to whom the poetic pendants of compliment and praising necklaces were stated and composed, as they were stated and composed to Shawqi. He was granted the title, "prince of poets," each one of his poems was considered Al-Asmaa (infallible), and every one of them was a venerable "Shawqiyah." This was how he was described by the newspapers and the narrators of his poetry.

He deserved much of this portrayal, as he was a poet of love and courtship, the versifier of incidents and history, the originator of brilliant proverbs and well-known sayings, the interpreter of national passion, the defender of religious belief, the hailer of the scholars of monuments, the reviver and awakener of determinations towards great deeds, the caller for union and rapport, the extractor of eternal facts out of dreams." (Al-Jemayel, 1930, p. 7.)

Antoine Al-Jemayel also said:

Shawqi was the poet of Islam and the poet of Egypt, and he was the greatest advertisement for Egypt during his life and after his death. Therefore, he had every right to boast, saying as he had said in one of his poems regarding Syria:

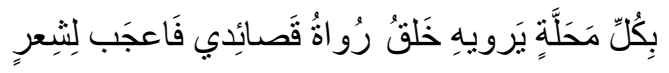

Around me are the narrators of my poems, so marvel at poetry that is narrated by people in every locality.

It is no wonder that there were many wise sayings, pieces of advice, and guidance in the poetry of the man who sang for religion and for his homeland. Shawqi's philosophy is a flowery wisdom; it is a bright, smiling philosophy in which there is no frowning, scowling, difficulty, or complexity. Instead, it looks like a brilliant doctrine and decent demand, which is not envisaged from in-depth analysis, but rather taken as it occurs to every human being and pronounced by every tongue. Shawqi would spontaneously scatter these intricacies in a line or two, or part of a line, so that they would appear like a delicious fruit between gorgeous blossoms, and his poetry would provide nutrition for the minds and irrigation for the hearts, at the same time as providing joy to the reader and tone for the listener (Ubeid, 1933, pp. 358-359). 


\section{The Source of Wisdom in Shawqi's Poetry}

The poet derived his oration, gleaned his wisdom, and picked his wise sayings from the following sources:
A. His wide cultural background inherited from his predecessors and their successors by reading, acquaintance, and knowledge
B. His long life experiences through which he fluctuated between alienation and stability, mixing with all strata of society
C. The political and intellectual conflict in his community.

The most important features of Shawqi's wise sayings are that he dressed them up with his poetry and kept them away from the dryness of boredom.

Shawqi used to write down every thought and would not let any of them escape him. He was among those who would stand awaiting prey to pierce with his arrow. That is why he succeeded in fishing and achieved what no other could. He would never say to himself, "Let us from this now because I am currently concerned about something else and will come back to it at another time." Innovative meaning was his target, however and whenever he showed it off. (Arsalan, 2009, p. 22)

In December 1932, Zaki Mubarak published unique research in the journal "Apollo," in which he talked about the intended wisdom and the innate wisdom in Shawqi's poetry (Mubarak, 1932). The first clear phenomenon in Shawqi's poetry is seeking the oddities of wisdom in all his poems and stanzas. This phenomenon is prominent, and not only in his later poetry, and it results from a personal tendency that existed since his youth. It is nice for a poet to be wise, and yet it becomes more beautiful when wisdom occurs spontaneously without pretension or fabrication. Shawqi often left the story style for the sake of wisdom. An example is the poem, "Major events in the Nile Valley," which was composed for The Tenth International Oriental Congress held in Geneva in 1894. It was a lengthy poem in which Shawqi described Egypt, its government, and its people since the times of the Old Testament. The stories were serially narrated and only interrupted by lines of wisdom, which were sometimes as long as five verses. One example is when he was talking about the humiliation that afflicted Egypt after the reign of the Pharaohs:

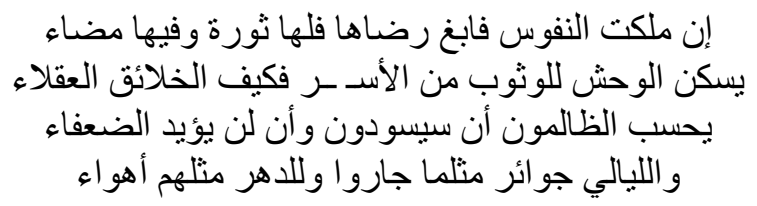

When you possess the souls, seek their satisfaction,

As they have a rebellion and sharpness.

Beasts calm down to jump out of captivity,

So how is it when it comes to wise creatures?

Tyrants miscalculate, thinking that they would dominate,

And that the weak would not be supported.

Yet, nights are as unjust as they,

and time has whims, just as they have.

(Appollo Journal, 1932, pp. 371-372) 
The following are other lines from the poem (a full translation is available in previous research (Al-Rifai, 2016):

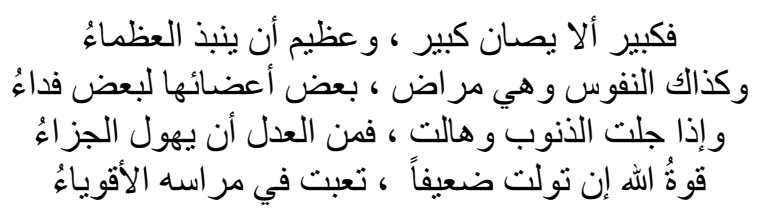

It is a gross omission when the great is not held in reserve,

And it is a great oversight to discard the great.

Souls, when ailed,

The limbs redeem each other.

When sins become enormous and huge,

It is fair that the penalty be terrifying.

God's power, when it takes care of the weak,

The powerful find it hard to overcome him.

In 1914, the British forced Shawqi into exile in Southern Spain in Andalusia, where he remained until 1920 when he returned to Egypt. These are selected lines from his first poem after returning to his homeland:

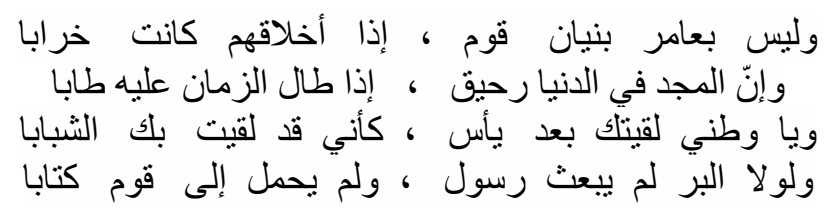

No construction of a folk could prosper,

If their morals are in ruins.

Glory is but nectar in this world,

Becoming better over time.

O my country, I met you after despair,

As if I met in you, youth.

It was only for charity that prophets were sent

And that holy books were carried to people.

\section{Bank of Egypt}

Celebrating the establishment of the Bank of Egypt on April 13, 1920, Shawqi glorifies money and its affairs:

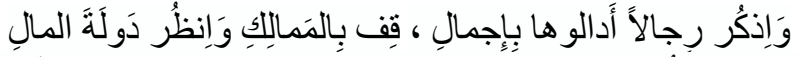

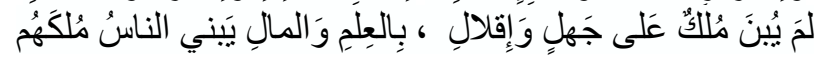

Stand at the Kingdoms and see the state of money, And mention the men who put it wholly into circulation. 
By science and money people build their kingship,

No kingship was built on ignorance and reduction.

\section{Wisdom addressing politics}

Many factors from the Turks had an influence on Shawqi, including the house of the Islamic Caliphate and its Pole Star, and the owners of Egypt's sovereignty, which had been crippled by the British occupation and whose blood ran in the veins of the poet's lineage of Edirne. This was one of the key cities in the Caliphate State and was captured by Bulgaria in 1912. Shawqi uses "Sister of Andalusia" to refer to Macedonia, which was seized from the Ottoman empire in 1913, drawing parallels between the case of Edirne and the case of Macedonia occupied by the West. Shawqi felt the enormity of the disaster while reliving the memories of the disaster for Muslims in Arab Andalusia. He was addressing the problem of the decline of Ottoman Muslim rule in its power and control.

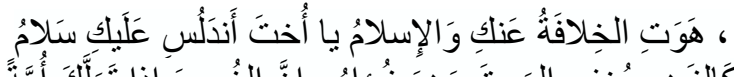

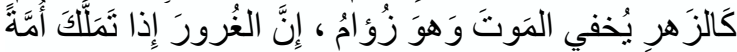

O sister of Andalusia, peace be on you,

The Caliphate and Islam fell down from you.

When vanity obsesses a nation,

It becomes like flowers hiding sudden death.

\section{"The Plight of Damascus."}

Among the attributes of Ahmad Shawqi's poetry were his faith in freedom, and among the poems that reflect this is "The plight of Damascus." When Syrians erupted against French colonizers to liberate their land, the French destroyed Syria using cannons, mercilessly shedding the blood of women and children in the streets. In January 1916, Egyptians held a popular conference that rejected the treacherous aggression and massacres, and Shawqi delivered his poem about the nations' freedom:

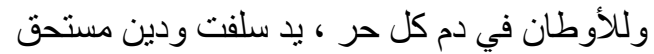

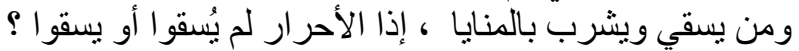

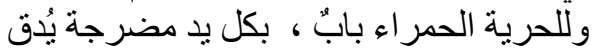

Homelands have, in the blood of those who are free,

A previous favoring hand and an owed debt.

Who would irrigate and drink from death,

If the free did not irrigate or drink?

Red freedom has a door,

Knocked on by every bloodstained hand.

(Abd. Al-Fattah, 1998, p. 114)

\section{The Milner committee}

On September 22, 1919, the Milner committee was formed by the British government to find out the causes of the 1919 revolution in Egypt. After serious rioting broke out in Egypt, Lord Alfred Milner was sent there on a mission from December 1919 to March 1920 to make recommendations on British-Egyptian relations-specifically, on how to reconcile the British 
protectorate established in 1915 with Sa'd Zaghloul's calls for self-government. On this occasion, Shawqi wrote a poem commenting on Milner's project:

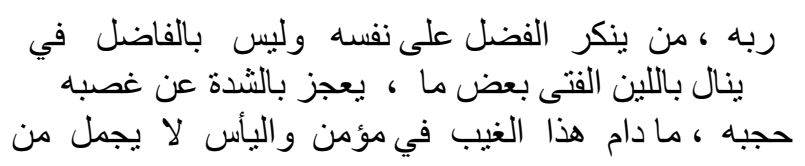

He is not a virtuous in his self,

The one who denies the credit of his Lord.

A lad my obtain through leniency, some of which,

He was unable to get by force.

Despair is not nice for a believer,

As long as the unseen is blocked by God.

The statement of February 28, 1922, laid the foundations for the political independence and the abolition of the British protectorate over Egypt. Commenting on this, Shawqi said:

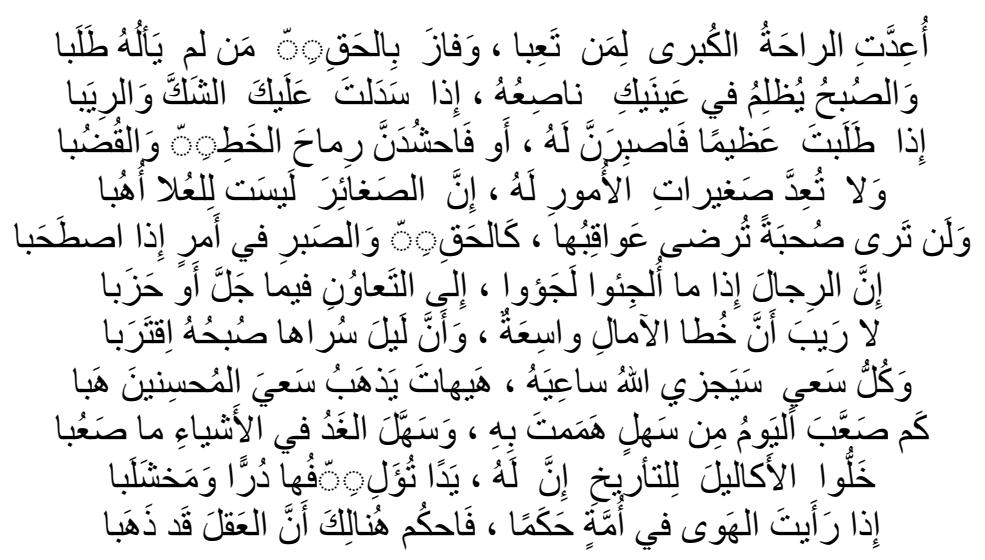

The greatest rest is prepared for those who toiled,

And those who won the right are those who spared no effort.

The whiteness of the morning darkens in your eyes,

If you drop on yourself doubt and suspicion.

When you demand a great thing, be patient till you get it,

Or mobilize for it great spears and bars.

Don't prepare for trivial things

Since they are not a good integument for highness.

You will not see a company whose consequences you accept,

more than rightness and patience when accompanied in an affair.

Men are those who, when they are resorted to,

Resort to cooperation, when great matters befall.

There is no doubt that hopes' steps are wide,

And the morning of the night's travelling has come near. 
Every seeking will be rewarded by God,

The charitable seeking will never go in vain.

Today has made difficult many easy things you intended to do, While tomorrow made difficult things easy.

Leave the crowns for history as it has,

A hand to design it with pearls and precious stones.

When you see that inclination is a judge in a nation, There you can judge that the mind has gone.

\section{The Eastern traveler}

Ahmad Hassanein made several trips to explore the Western Desert of Egypt and Libya, the first of which was in 1920 with Rosetta Norris, an English lady. The aim was to discover unknown water sources to open new Sahara routes from Kufra to Sudanic Africa. In September 1924, his famous report was published in National Geographic Magazine. He was honored with the title of Bey and the prestigious Founder's Gold Medal of the British Royal Geographical Society that year. Commenting on Hassanein's famous trips, Shawqi said:

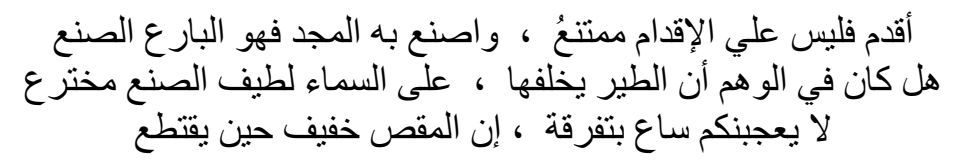

(Go ahead), be intrepid, there is no abstention for intrepidity, and create by it the glory, as it is the clever maker.

Was it ever in the fantasy that the birds would be succeeded over the sky by a nicely made invention.

Do not be fascinated by someone who stirs up discord among people, The scissors are light when they cut out.

In the same poem, he advises:

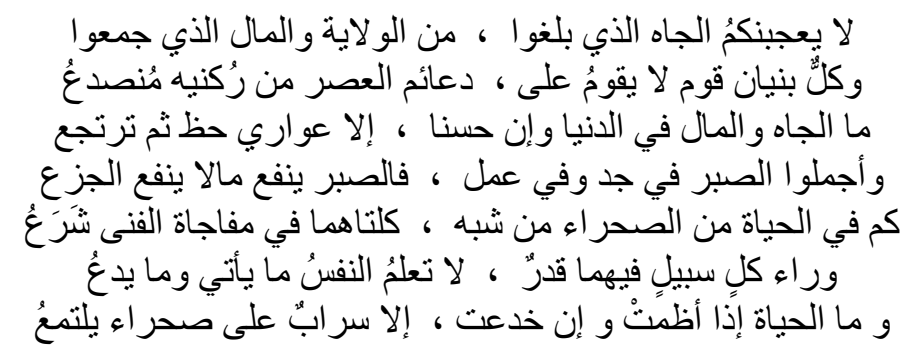

Do not be fascinated by the prestige they have attained from authority, and the money they collected.

Every construction which is not based upon the pillars of its time falls from its corners. 
Wealth and money in the worldly life, even though good, are nothing but lucky strikes, and subsequently they are retaken.

Be patient while working hard,

Good patience benefits where money is of no use.

How much life resembles the desert!

Both of them are surprising death sails.

Behind each of its ways there is a fate,

The soul does not know what comes and what is left.

Life when it makes us thirsty, and when it deceives us,

Is nothing but a glittering mirage in the desert.

\section{Wisdom in Egyptology}

In his introduction to Shawqi's first poetry collection, Dr. Muhammad Hussein Heikal (18881956) writes:

As you read Shawqi's poems, "at the foot of the pyramids," "The Sphinx," and "Tutankhamun," you become touched by these images of the past in its sanctity and esteem. You become obsessed by the poet soul that lifts you above the level of this worldly towards the eternal heavens." (Shawqi, n.d., p.11)

In his poem, "Tutankhamun," Shawqi writes:

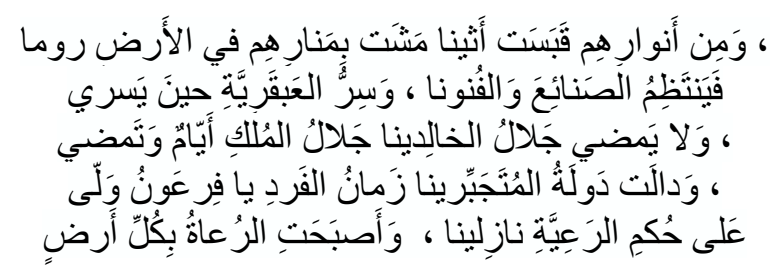

By their Illumination Rome walked through Earth,

And from their lights, Athens was extracted.

When the secrecy of genius applies,

Skills and arts are organized.

The glory of Kingship stays for days then goes away,

While the glory of the immortals never goes away.

O Pharaoh, the time of the individual has expired, And the state of tyranny has come to an end.

Pastors in all lands now,

Obey the rule of the parish.

\section{Wisdom in education}

In his famous poem, "Stand up for the Teacher," Shawqi provides a multi-dimensional picture of the reality of societal knowledge. It is a mixture of old and new with an inbuilt bitterness as if observing the cognitive retardation from which the children of his homeland were suffering. 
The poem contains an overwhelming anger at those who are responsible for this underdevelopment in education. Shawqi also ridicules the collapse of civilization in comparison with current overall achievements and measured in comparison to past Egyptian accomplishments:

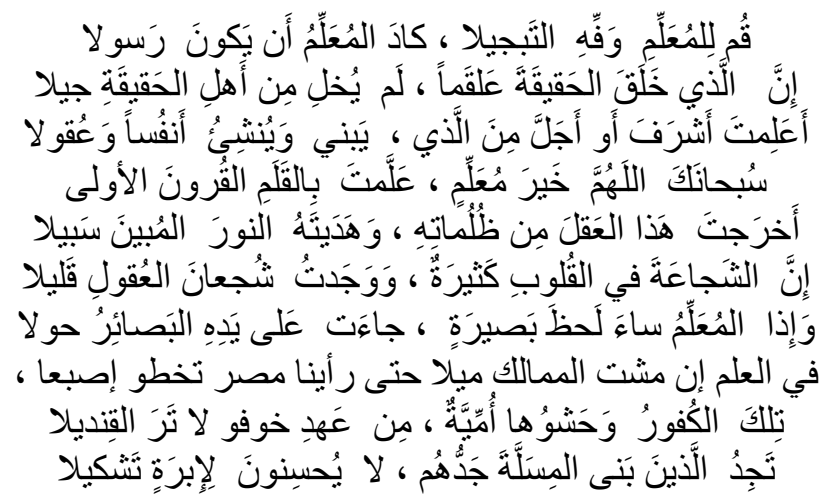

Rise up for the teacher, and pay him his due honor in full,

For the teacher is almost a messenger.

God, the One who created truth as bitterness,

Left no generation without the people of truth.

Have you known anyone more honorable and dignified

Than the one who builds and upbrings the souls and minds?

Glory be to You, O God, You are the best teacher,

You taught by the pen in the early centuries.

You took this mind out of darkness

and guided it to the road of clear light.

Bravery is found in many hearts,

Yet I found few people with brave minds.

When the teacher worsened in regard to insight,

The insights became cross-eyed on his hand.

We have seen Egypt step an inch in knowledge,

When other kingdoms have covered miles.

Those hamlets are stuffed with illiteracy and

Since the reign of Cheops have not seen a lamp.

Those whose grandfathers who built the obelisk

Cannot form a needle.

Teachers are excused here because they do a tedious job and are frustrated by the colonizers and the ignorance of parents. This ignorance invalidates at night what the teachers weave during the day. Consequently, children are orphaned by ignorance and illiteracy in the lives of their parents. Accordingly, Shawqi addressed teachers in the same poem, saying: 


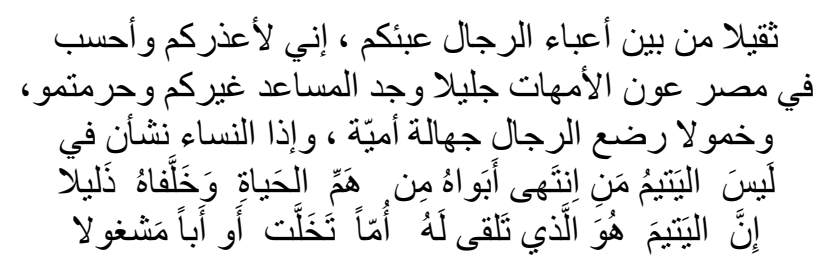

I excuse you and figure that your burden

Is a heavy one among the burdens of men.

Others found an assistant while you were deprived

In Egypt from the mothers' aid.

If women are raised in illiteracy,

Infants suckle foolishness and sluggishness.

The orphan is not the one whose parents passed away

From life's worry, leaving him humiliated.

The orphan is the one whose mother abandoned him,

Or whose father is busy.

Lamenting the weakness of ethics, he continues:

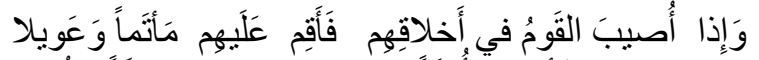

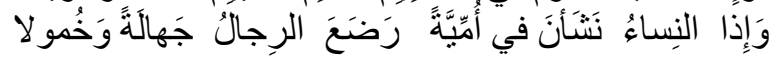

If a folk were injured in their morals,

Hold obsequies and mourn for them.

When women are raised illiterate,

men are nursed with foolishness and lethargy.

\section{Cairo University}

A celebration ceremony was held for the founding of Cairo University on March 31, 1914. In the marquee celebration, poetry for this occasion was recited to Khedive Abbas Hilmi II and guests. The poem is one of the marvels of the Prince of Arab Poets, Ahmad Shawqi, thanking Princess Fatima, daughter of Ismail, who donated proceeds, possessions, and her own jewelry to set up this university:

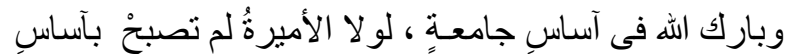

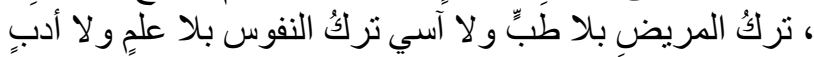

May God bless the basis of a university,

Which without the princess, would have no basis.

Leaving the souls without knowledge and literature

Is like leaving the patient without medicine or physician.

\section{My friend the book}

Presenting the book as a best friend, Shawqi writes: 


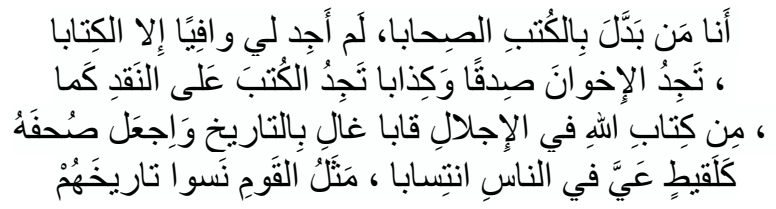

I am the one who exchanged friends with books,

I did not find anyone loyal to me except books.

You will find books on criticism, and like brothers, some are honest others are liars.

Exceed in history and make its pages,

Near God's book in reverence.

People who forgot their history

Are like a foundling who searched aimlessly for his lineage among people.

\section{Wisdom in religion}

The prophetic praising poem "Hamzia" was presented for Prophet Muhammad, peace and blessings be upon him, on the occasion of his "Mawlid" (holy birthday anniversary). There are further pearls of poems which contain meanings with which no one could disagree:

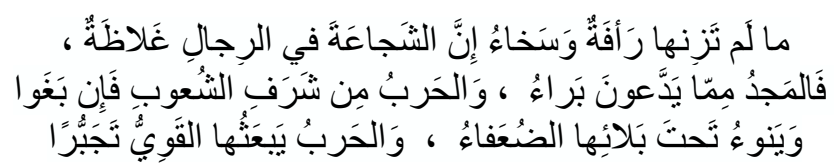

The courage in men is harshness,

Unless weighed by compassion and generosity.

War is of the nations' honor, yet if they outrage,

Then glory is clear of what they claim.

War is sent tyrannically by the strong,

While the weak collapse beneath its plague.

On religious tolerance, Shawqi said:

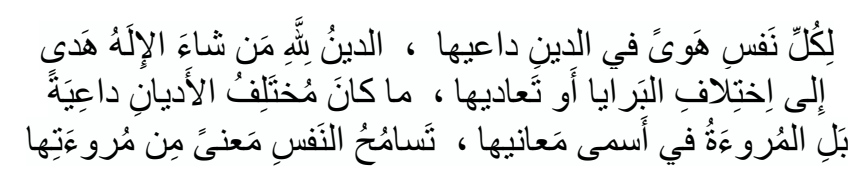

Religion is for God, whomever God wills, He will guide,

Each soul has an inclination to which it is called.

The difference of religions should not be a cause

Of difference and enmity between humans.

The soul's tolerance is part of its magnanimity,

It is it in its highest sense.

Singing for universal peace, Shawqi writes: 


$$
\begin{aligned}
& \text { جبريل أنت هدى السماء وأنت بر هان العناية } \\
& \text { ابسط جناحيك اللذين هما الطهارة و الهداية }
\end{aligned}
$$

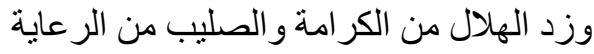

$$
\begin{aligned}
& \text { فهما لربك راية و الحرب للثـيطان راية الثراية }
\end{aligned}
$$

(Gabriel), you are heaven's guidance and the divine proof,

Spread out your wings as they are purity and right guidance.

Add honor to the (Crescent) and care to the (Cross.)

They are God's flag, while war is the devil's flag

Shawqi praised morality, making it the basis for the life of nations and a source of delight. In a poem entitled, "The Pardon of the Capable," Shawqi writes:

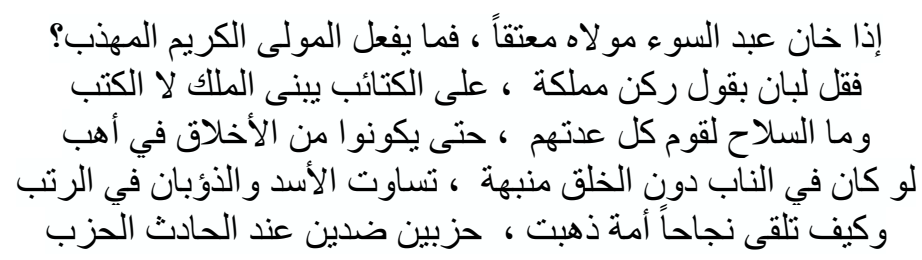

If the bad, released slave betrayed his master,

What should the noble, polite master do?

Tell the one who builds, by words, a corner of a kingdom.

Kingdoms are built by battalions, not by books.

And arms are not a people's total equipment, Till they become prepared by ethics.

If the fangs were better than manners,

Lions and wolves would be of equal ranks.

How could a nation succeed,

When it diverted into two opposite parties upon a severe incident?

Shawqi wrote many poems urging kindness, compassion for the weak, and calling for everything that raises up Egypt and the East. His poetry is also full of wisdom and adherence to righteous morals. In his poem, "The Red Crescent," he writes:

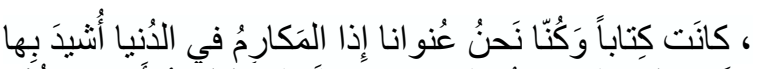

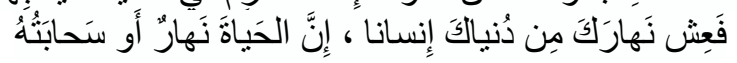

When noble deeds receive tribute in this worldly life,

It becomes a book and we become its title.

Life is a day or its light,

So live your worldly day life as a human. 
He writes:

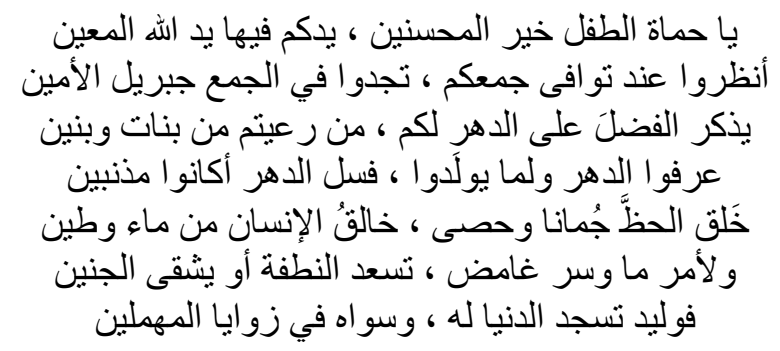

Oh protectors of child best benefactors,

In your hands was the aiding hand of God.

Look at your gathering when it consummates,

You will find among them the faithful angle Gabriel.

Your favor will be kept to you as long as time,

By the girls and boys whom you sponsored.

They knew the burden of time before they were born,

So ask time if they were guilty.

God was the one who created luck; pearls and pebbles,

The Creator of the human, from water and mud.

For a certain matter and a mysterious secret,

There is a happy sperm or an unhappy embryo.

There is a newborn prostrated by the world,

While others are in neglected corners.

In his poem, "The Mother of Charity," he writes about the mother of Abbas II Hilmi Pasha, the last Khedive (Ottoman viceroy) of Egypt and Sudan, ruling from 8 January 1892 to December 1914. She died in Istanbul in 1931.

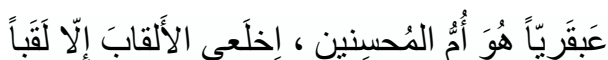

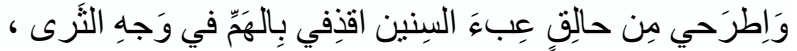

Strip off the titles except one genius title,

Which is "mother of the charitable."

Throw worry in the face of the ground,

And drop from your head the burden of the years.

\section{Wisdom in love}

There is overflowing evidence in Shawqi's poetry of the innate wisdom that lies naturally within its folds without pretention or affectation. For example:

$$
\begin{aligned}
& \text { يا لائمي في هو اهو الهوى قدر ، لو شفلك الوجد لم تعذل ولم تلم }
\end{aligned}
$$

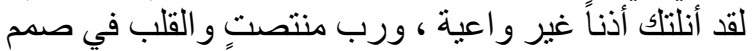


0 you who blame me her love, it is but a fate,

If you were but burnt by it, you would not reproach or blame.

I gave you an unconscious ear,

The ear might hear, while the heart is deaf.

"I once talked to Dr. Taha Hussein about Shawqi's wonderful line of the proverb, 'love is a fate,' Taha commented smilingly." It was written, promised, and destined on the forehead!" (Mubarak, 1988, p. 373).

In the same poem, Shawqi describes this worldly life:

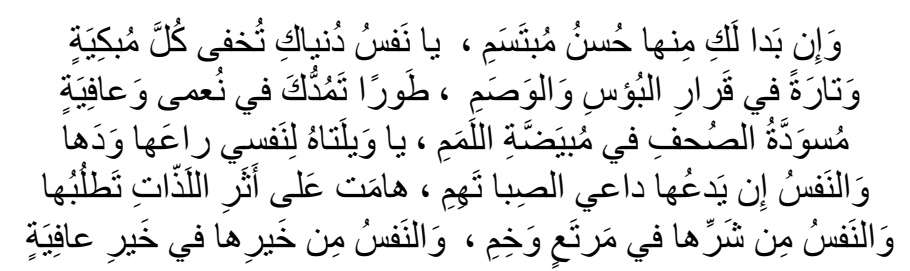

O soul, your worldly life hides every wailing incident, even if what appears to you looks good and smiley.

Sometimes, it provides you with grants and wellness, Others, it leaves you at the bottom of misery and disgrace.

Woe unto myself, it was appalled and shocked, By its blackened pages of deeds, and whitened temple hair.

It wandered aimlessly after the pleasures, requesting them.

The self, when called by boyhood, answers.

The good soul is in wellbeing, And the evil is in a wicked sink.

The following Shawqi poem, "Ask my heart," includes a wonderful collection of his wise sayings. This poem begins smoothly and quietly and, in its forefront trend and like all traditional Arabic poems, it tends to the affairs, heart whispers, and confusion about what the heart grips out of the body according to the Arab vision. In this poem, Shawqi explores and becomes engrossed in several classic poetic themes, such as courtship, wisdom, and social guidance, stressing the need to promote education in an atmosphere of facilitation, tolerance, and optimism. Shawqi, as usual, mixes praise with current concerns for the national aspirations of his people, who were living under British occupation.

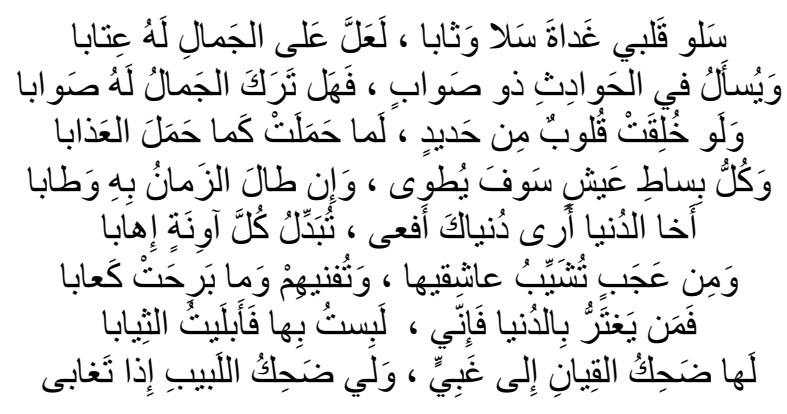




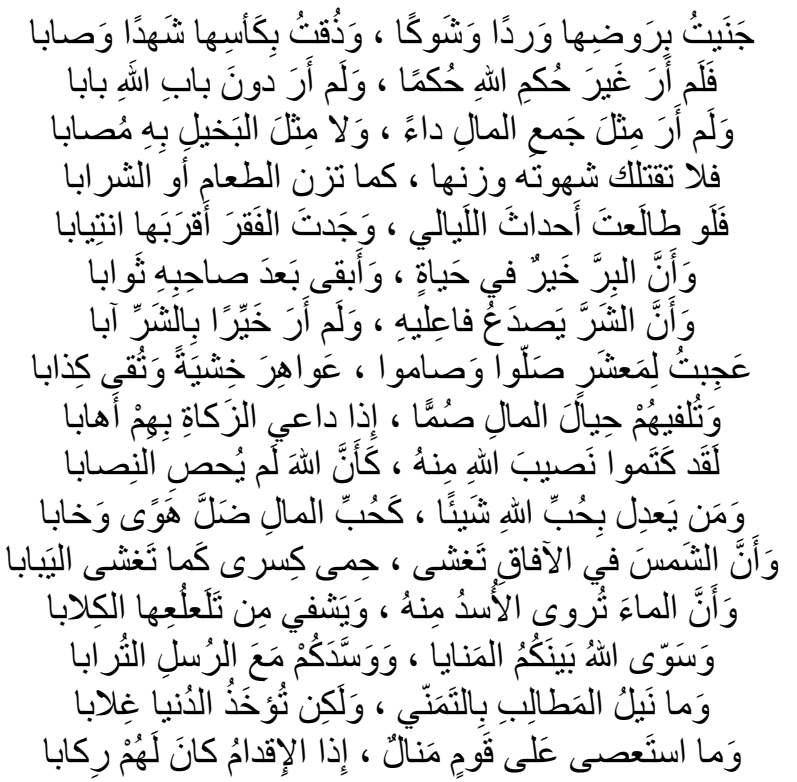

Ask my heart the morning it consoled itself and recovered its sense, As it might like to blame beauty.

It asks reason about what happened,

Since beauty left him no reason.

If there were hearts created from iron,

They would not have bared the load of agony as it did.

Every life carpet will be folded,

However long and pleasant it was.

O lover of worldly life, I see the world as a snake,

Changing its skin every now and then.

How wonder she makes her lovers white-haired,

And exterminates them, while she remains a young full-breasted maiden.

I tell those who are deceived by this worldly life,

I had dressed in it and had worn out many clothes.

It has the laughter of the slaves to a dunce,

While I have the laughter of an intelligent who plays dumb.

I harvested roses and thorns in its garden,

Tasted honey and calamity from its cup.

I have seen none but God's judgment as a judgment, No door beneath His door.

I have seen no illness like collecting money, And none like a miser afflicted by it. 
Do not be killed by its lust,

Weigh it as you weigh food and drink.

When you look at the nights' incidents,

You will find poverty the nearest to befall.

Righteousness is goodness in life,

And its reward remains longer than its doer.

Whereas evil slams its doers,

I never saw a good person who gained from evil.

I am astonished by folk who pray and fast,

With false fear of God and lying piety.

You find them deaf when it comes to money,

When the charity caller appeals to them.

They concealed God's share of it,

As if God did not count its quorum.

He who equalizes the love of God with anything else,

Like the love of money, becomes misled and lost.

The sun on the horizons spreads over

Caesar's sanctuary as well as wastelands.

Lions are irrigated by the same water

That quenches the dogs' thirst.

God made you equal in death,

And pillowed you, as well as the apostles, by earth.

Demands are never obtained by wishes,

But life is taken by dominance.

No obtainment defied any folk,

Had they ridden courage.

In another love poem, Shawqi writes:

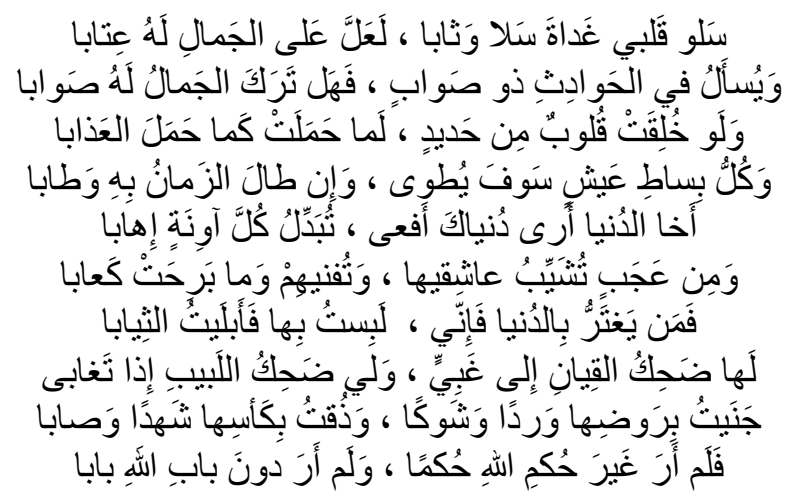




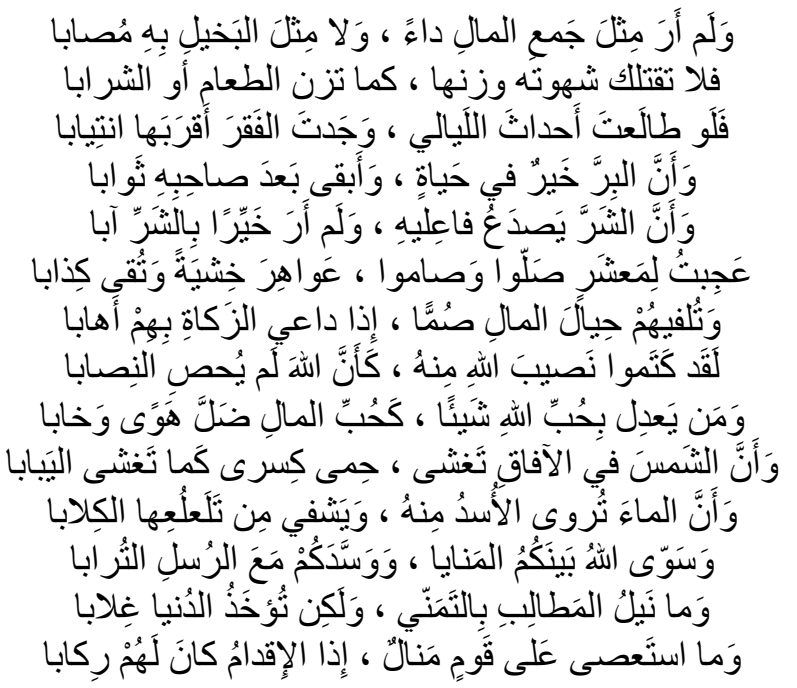

I buried my dreams with a crying heart,

And collected my net, leaving the beauties' roads.

I turned back from the youth's runways and its flowers,

Walking on thorns in their whereabouts.

Within my side was a weak fellow, whose beatings,

When it looked around, had burst into tears.

It scared him that I folded my traps,

After a lengthy tying and untying.

Woe to my side's son, the utmost of every pleasure,

After youth, is too dear to attain.

0 my heart, no remainder was left of us,

For chivalry, or a leftover for a fight.

When you applauded, we used to anticipate love, And stretch tight like a devastating band.

Today, when you shake me, you trigger within me That which the bell triggers within the hermits.

O neighbor of the valley, I was enchanted and visited

By what looked like dreams of your remembrance.

I recalled your love in memory and in sleep,

Since memories are the years' narrating echo. 


\section{Wisdom addressing death}

Avowing life's pleasures, Shawqi writes:

$$
\text { روحوا القلب بلذات الصبا ، فكفى الثيب مجالا للكدر }
$$

Amuse the heart by the pleasures of boyhood,

Gray hair is sufficient for old age.

Subsequent poems contain masterpieces of wisdom addressing death, seeking asceticism, and turning away from the worldly life. In a poem on the tomb of Napoleon, he writes:

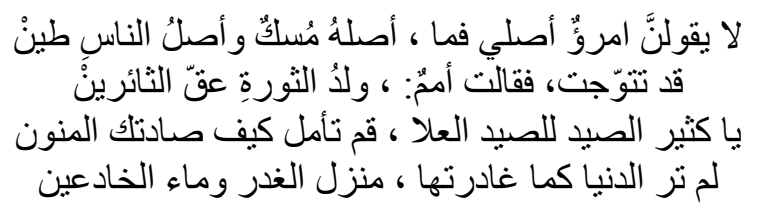

No man should be proud of his origin (lineage),

Was his origin musk, while other people's clay?

When you were crowned, nations said,

The son of revolution was ungrateful to the rebels.

0 you multi-fisher, fishing highness,

Consider how you were fished by death.

You have not seen the world as when you left it,

Home of treachery and the swindler 's water.

In a mourning poem dedicated to his friend, the political leader Mustafa Kamil Pasha (18741908), Shawqi writes:

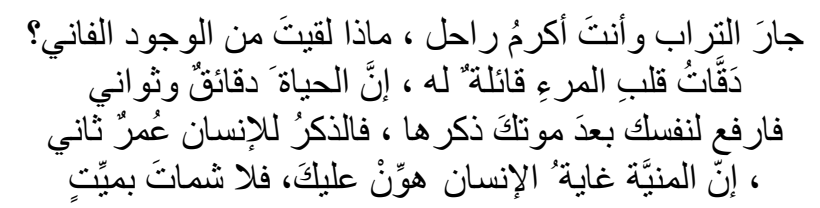

O Neighbor of dust, most honorable departed,

What have you received from the mortal existence?

Man's heartbeats tell him

That life is minutes and seconds.

So raise for yourself its after death remembrance,

As it is a second life for the human being.

Take it easy, there is no glee for the dead,

Death is the end of man.

For Boutros Nayruz Ghali Pasha (1846 -1910), prime minister of Egypt from 1908 to 1910, he writes: 


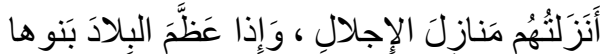

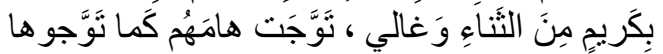

If the country is glorified by its sons,

It will lodge them in homes of reverence.

It will crown their heads as they had crowned its,

By noble and precious praise.

Shawqi laments the Russian writer Count Lev Nikolayevich Tolstoy (1828 -1910):

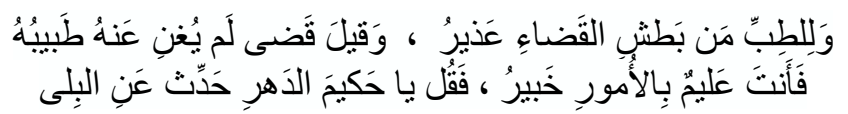

It was said that he had died and his doctor was of no use to him,

Medicine is excused from fate's oppression.

Tell us, about decay, o time's wise man,

As you were an expert who was knowledgeable in affairs.

The following honors Mustafa Fahmi Pasha (1840-1914), an Egyptian politician who served in several different cabinet positions and as a prime minister two times. Fahmi's daughter, Safiya, was a political activist, a significant figure in Egyptian society, and wife of Sa'd Zaghloul:

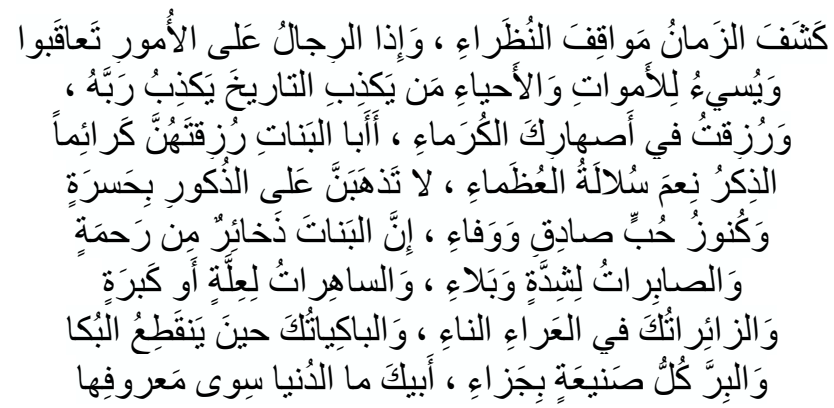

When men succeed each other on affairs,

Time uncovers the counterparts' position.

Whoever lies about history lies about God,

And offends the dead and the living.

0 father of girls, you were granted by them,

And were granted by noble sons in law.

Do not sigh for not having sons,

Good reputation is the dynasty of great men.

Girls are the reservoir of mercy,

And treasures of honest love and loyalty.

They are the wakeful upon illness or oldness,

And the patient upon hardship and affliction. 
They are your mourners when mourning stops,

And they are your visitors in the remote open.

This worldly life is not worth but its beneficence, And charity does pay.

Muhammad Farid Beck (1868-1919) was an Egyptian political figure, a nationalist leader, writer, and lawyer:

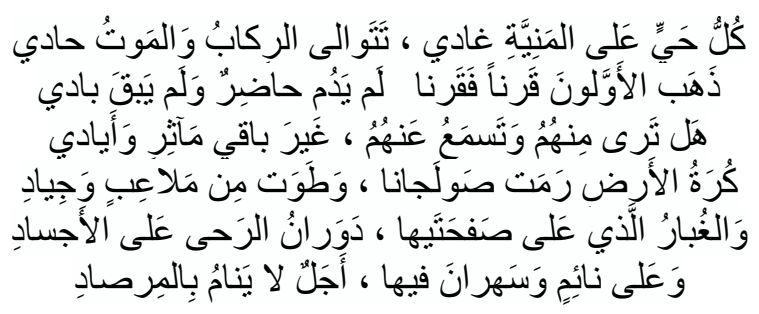

Every living person is travelling towards death,

In successive convoys, while death is the driver.

The ancients went away century after century,

No urban lasted, no inurbane remained.

Do you see or hear them?

Except for their exploits and generous hands?

The globe threw away scepters,

And folded playgrounds and horses.

With dust on both pages

Is the mill's rotation on the bodies.

Over its sleepers and the awake,

There is a watchful appointed moment of death.

Othman Ghalib Pasha (1845-1920) was an Egyptian physician and botanist. He did valuable research about worms published in Europe and Egypt. The most important of his works were "Invertebrate zoology" (1886) his book, "A summary of the plant parts and their functions" (1887), and research about types of smoke and tobacco in Egypt. Ghalib also wrote about the cotton leaf worm in 1879 and described how to exterminate it. After his retirement in 1898, he emigrated to Switzerland, where he died on January 28,1920, and was buried near the city of Montreux according to his will (Ghirbal, 1995):

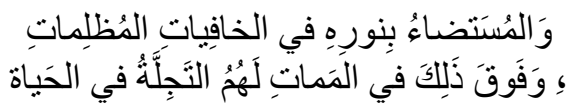

Those by whom people are enlightened in the unknown darkness, To them is glorification in this life and in death.

Sayed Darwish (1892-1923) was an Egyptian singer and composer. He is considered the father of Egyptian popular music and is one of Egypt's greatest musicians: 


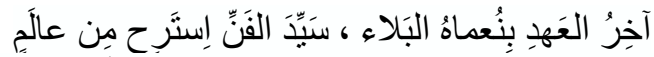

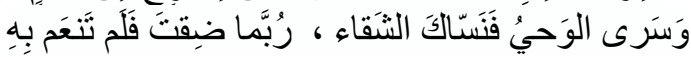

0 master of art have rest from a world, In which scourge is its last period.

Perhaps you were fed up. No longer enjoying life,

Hence came the angle, who made you forget misery.

Ahmad Shawqi used to generally overview the Egyptian political field and extrapolate lessons from it. He did not let an incident pass without showing his opinion, apart from taking sides. He therefore addressed the leaders in 1925 on the memory of Mustafa Kamel with a poem on the occasion of the death of Lord Karnervon, who funded Howard Carter's mission for the exploration of the tomb of Tutankhamun. Karnervon attended the opening of the pharaoic cemetery and died six months later. Rumors about his death spread because of the curse of the pharaohs. Shawqi writes:

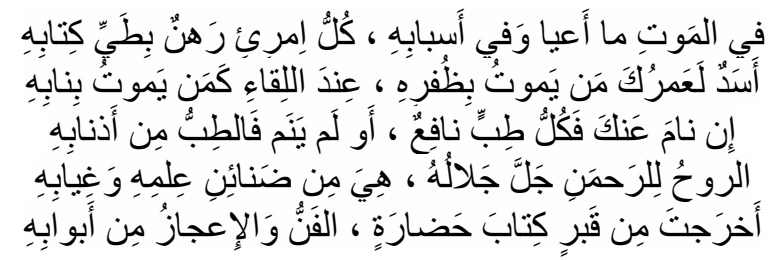

In death and its causes are astounding things.

Every man is subject to the book of his deeds.

By your life, whoever dies by the lion's fang, when facing it, is like he who dies by its nail.

When death overlooks you, every medicine is wholesome.

When not, medicine is of his cronies.

The soul belongs to The All Compassionate, The Almighty, It is among His unseen knowledge.

You took out of the grave a book of civilization, Art and inimitability are of its doors.

Sa'd Zaghloul Pasha (1859 -1927) was an Egyptian revolutionary and statesman and leader of Egypt's nationalist Wafd Party. He served as prime minister of Egypt from January 26, 1924, to November 24, 1924. Shawqi writes:

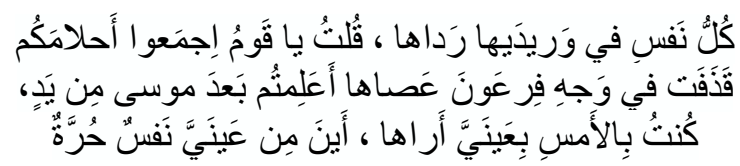

I said: 0 my people collect your dreams,

In the veins of every soul, lies its death.

Did you know, after Moses, a hand

That threw in the face of Pharaoh his stick? 
Where from my eyes is a free soul?

Which I used to see in the recent past, with my own eyes.

Abdel Khaliq Tharwat Pasha (1873-1928) was an Egyptian political figure who served as the prime minister of Egypt from March 1, 1922, until November 30, 1922, and again between April 26, 1927, and March 16, 1928. He negotiated with the British after the 1919 revolution and arrived at the statement of February 28, 1922, which ended the British protectorate of Egypt. He died in Paris in 1928 at the age of 55.

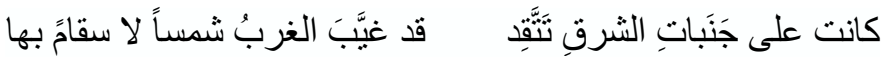

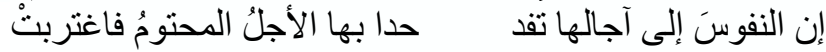

The west has taken away a healthy sun,

That was glowing on the sides of the east.

The inevitable appointed time of death drove it, and thus estranged,

Souls move toward their appointed moment of death.

Prince Saif was the son of the ruler of Yemen, Imam Yahya bin Hameed Al-Deen. On April 24, 1932, he drowned in the sea of Hodeida when trying to save his secretary. When the sad news reached Shawqi, he wrote a touching lament poem. Here are two lines:

$$
\begin{aligned}
& \text { الخط ييقى زماناً بعد كاتبهُ، وكاتب الخط تحت الأرض مدفونا } \\
& \text { و الذكر ييقى زمانا بعد صانعه ،وخالا لأل الذكر بالاحسان مقرونا }
\end{aligned}
$$

The courageous doom is not due to courage,

Nor does cowardice extend the age of the cowards.

But when the lad's time comes,

He spends, while if not, he lives.

\section{CONCLUSION}

How true it was Shawqi when he wrote:

$$
\begin{aligned}
& \text { الخط يبقى زماناً بعد كاتبهُ، وكاتب الخط تحت الأرض مدفونا }
\end{aligned}
$$

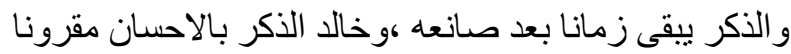

The writing remains an age after its writer,

While its author is buried underground.

Good reputation remains an age after its maker,

Eternal reputation is associated with charity.

All of these previous poems clearly show that the poet's soul yearned for all the varied meanings of existence, and that it was stimulated by the meaning of beauty, wherever it was and no matter how many paths it took. Thus, Shawqi was like a philosopher whose horizon widened for all ideologies, opinions, and various doctrines which always seek the truth and beauty and yearn for the presence of the noblest that is granted by God. According to Mansour Fahmi: 
"It is also only right to point out a particular reference in Shawqi's poetry which looks at the meanings of memories, those meanings that are called psycho-time by philosophers. That which is reflected in Shawqi's poetry is but the elite of human poetry, shaking hearts because it discloses the most significant thing that time harbors and the purest of what remains of human memories."

(Ubaid, 1930, p. 501)

\section{References}

Al-Jarim, A. (1992). Al-Jārimīyāt. Cairo, Egypt: Dar al-Shurouq.

Mubarak, Z. (1988). Ahmad Shawqi. Beirut, Lebanon: Dar Al-Jeel.

Ghirbal, M. Sh. (1995). Simplified Arabic encyclopedia, Volume II. Cairo, Egypt: Dar-Al-Jeel.

Mubarak, Z. (1932). Appollo Journal. pp. 371-372.

Al-Rifai, N. (2016). The Influence of The Greco-Roman Literature on the Poetry of Ahmad Shawqi. In Al-Rifai, N. (Ed.), Ahmad Shawqi Prince of Arap Poets. Saarbrücken, Germany: LAP Lambert Academic Publishing GmbH \& Co. KG

Ubeid, A. (1933). Dhikra al-Sha'irayn. Beirut, Lebanon: Alam Al-Kutub.

Al-Jemayel, A. (1930). Shawqi Sha'er Al-Umara. Cairo, Egypt: Matba'at Al-Ma'aref.

Arsalan, Sh. (2009). Shawqi wa Șadaqat Arba'in Sanah. Al-Shouf, Lebanon: Al-Dar al-Taqaddumiyah.

Jabri, Sh. (1997). Dirasah an Shawqi. Damascus, Syria: Dar Qutaybah.

Abdul-Wahab, S. (1987). Islamiyat Ahmad Shawqi. Cairo, Egypt: Maktabat Madbouli.

Al-Dusouqi, O. (1951), Fe Al-Adab Al-Hadeeth, part II. Cairo, Egypt: Dar Al-Fikr Al-Arabi.

Al-Rafi'ei, M. (2001). Min Wahy Al-Qalam part 3. Beirut, Lebanon: Al-Maktaba Al-Asriya.

Shawqi, A. (n.d.). Al-Shawqiyat. Beirut, Lebanon: Dar Al-Ketab Al-Arabi.

Daif, Sh. (2010). Shawqi Sha'er Al-Asr Al-Hadith. Cairo, Egypt: Al-Hai'a Al-Masriya Al-Amma lil Kitab.

Abd-Al-Fattah, A.(1998). Shakhsiyat Adabiyah. Hawalli, Kuwait: Maktabat Ibn Kathir. 